\title{
Trends in pre-school enrolment in Turkey: unequal access and differential consequences
}

\section{Orhan Agirdag, Zeliha Yazici \& Sven Sierens}

To cite this article: Orhan Agirdag, Zeliha Yazici \& Sven Sierens (2015) Trends in pre-school enrolment in Turkey: unequal access and differential consequences, Comparative Education, 51:4, 537-554, DOI: 10.1080/03050068.2015.1081796

To link to this article: http://dx.doi.org/10.1080/03050068.2015.1081796

曲 Published online: 17 Sep 2015.

Submit your article to this journal $\overline{ }$

山 Article views: 54

Q View related articles $₫$

View Crossmark data $₫$ 


\title{
Trends in pre-school enrolment in Turkey: unequal access and differential consequences
}

\author{
Orhan Agirdag ${ }^{\mathrm{a}, \mathrm{b} *}$ (1) , Zeliha Yazici ${ }^{\mathrm{c}}$ and Sven Sierens ${ }^{\mathrm{d}}$ \\ ${ }^{a}$ Department of Education, University of Amsterdam, 1018WS Amsterdam, The Netherlands; \\ ${ }^{b}$ Laboratory for Education and Society, University of Leuven, Andreas Vesaliusstraat 2-bus \\ 3761, 3000 Leuven, Belgium; ${ }^{c}$ Department of Preschool Education, Akdeniz University, \\ Kampus 07058, Turkey; ${ }^{d}$ Centre for Diversity and Learning, Ghent University, 9000 Gent, \\ Belgium
}

\begin{abstract}
In this study, a historical and international analysis of early childhood education in Turkey is made. More specifically, we explore the trend in pre-school enrolment, compare Turkey's enrolment rate with other countries, study whether access to pre-school is related to social class and gender, and investigate the impact of pre-school attendance on later academic performance. We use data from the PISA (Programme for International Student Assessment) 2012 study and World Bank EdStats. The results indicate that Turkey's pre-school enrolment has strongly increased over the years. However, compared with other (newly) industrialised countries, Turkey has a very low pre-school enrolment rate. Regression analyses revealed that pupils from wealthy families are much more likely to attend pre-school than pupils from poor families, while no difference was found between girls and boys. Importantly, pre-school attendance was related to higher academic achievement, even though pupils from wealthy families benefited more than middle-class and poor pupils.
\end{abstract}

\section{Introduction}

The amount and nature of pre-school ${ }^{1}$ experience that a child has before starting school are two of the claimed keys to success at school (Hattie 2013). A widespread perception among academics, educational practitioners and policy-makers is that participation in high-quality pre-school has evident benefits for all children in terms of school readiness, educational achievements and social adjustments (Boocock 1995; Karoly, Kilburn, and Cannon 2006). It is likewise believed that early childhood education for disadvantaged children can reduce the likelihood of school failure and improve their life chances and ultimate well-being (Entwisle 1995; Lamy 2013). Indeed, if pre-school education is targeted at disadvantaged children or if disadvantaged pupils show the largest gains from pre-schooling, it will reduce the achievement gap between advantaged and disadvantaged children (Heckman 2006). The importance of pre-schooling can hardly be overstated since in early childhood, children's cognitive and social-emotional skills develop rapidly and are sensitive to 'inputs' from both home learning environments, and education and care settings. Thus, a frequently made assumption is that pre-school could compensate for a lack of very fundamental skills not acquired at home, such as academic language proficiency (Agirdag, Van Avermaet, and Van Houtte 2013; Leseman 2002).

*Corresponding author. Email: orhan.agirdag@gmail.com 
Given the importance of the topic, various international organisations such as European Commission, UNESCO, Organisation for Economic Co-operation and Development (OECD) and the World Bank have shown their commitment to promote early childhood education. For instance, UNESCO leads and coordinates the Education For All (EFA) movement since 2000. EFA focuses on the need to provide learning opportunities at every stage in life and the first EFA goal is the expansion of early childhood education. The progress made across the globe is monitored in the so-called Global Monitoring Reports (GMR) (see EFA GMR 2003, 2006, 2015). The OECD closely monitors the early childhood education policies and development in the member states in the 'Starting Strong' reports (see OECD 2001, 2006, 2015). Between 1984 and 2015, the World Bank has financed 123 projects on pre-primary education, for a total value of about \$900 million (see World Bank's website). The European Commission states that 'a solid start by providing quality early childhood education is central to the European strategy for smart and sustainable growth, the European Union (EU) 2020 strategy' (European Commission 2014, 3). The most important reason why these international organisations support early childhood education is that they believe that it can bring a wide range of benefits for children, parents and society at large. Most importantly, early childhood education is believed to increase the level of human capital of the country, directly through improved educational performance and indirectly through increased availability of a female workforce. Another reason is the assumption that if children from lower socio-economic background can start schooling early, their disadvantaged start can be compensated for to a certain extent through pre-schooling.

Countries vary in models of pre-school provision. In some countries such as France, the Netherlands, and Japan, pre-primary education is nearly universal, whereas other countries such as Argentina, China, Mexico and Uruguay are moving rapidly to increase provision (OECD 2010, 2013). This study is conducted in Turkey, where provision of and participation in pre-schooling are exceptionally low. Over the last decades, Turkey has invested increasingly on pre-primary schooling (Kapc1 and Güler 1999; World Bank 2013). However, there are no studies that focus on early childhood education from an historical and international comparative perspective. Our aim with this study is to fill this research lacuna. Based on a review of the literature, the following research questions are established and will be empirically investigated:

1. What is the long-term trend of the pre-school enrolment rate in Turkey?

2. What is the current pre-school enrolment rate when compared with other countries?

3. Is access to pre-school determined by social class and gender background?

4. Is pre-school attendance related to future academic achievement?

5. Do the effects of pre-school attendance on academic achievement vary according to social class?

\section{Pre-schooling in Turkey}

\section{Historical developments}

The history of pre-school education in Turkey dates back to the Ottoman Empire period. Already in the fifteenth century, schools called Sibyan Mektebleri (child schools) provided religious education and a very basic instruction to 3-6-years-olds (Akyüz 1996). However, it should be noted that the Ottoman Empire did not see 
education as a public service. This perspective was transformed in the nineteenth century with the so-called Tanzimat (reorganisation) reforms which attempted to modernise the empire. Nevertheless, it was only with the Second Constitutional Era (after 1908) that the educational institutions were reorganised in a 'Western' secular way (Gökçe and Oguz 2010). Therefore, it is not a coincidence that the first nursery schools were only established after 1908 (Akyüz 1996; Duru 1915). The first pre-schools were not set up for educational or pedagogical purposes, but they were in fact a part of the ongoing massive reforms that mimicked all aspects of Western education. Not only was the idea itself taken from Western societies, but also the pedagogy used in these nursery schools was based on a Western approach, that is, the Fröbel approach (Akyüz 2008; Ergin 1977).

The proclamation of the Republic in 1923 brought a reorganisation of education. When the Republic was founded, Turkey had in total 80 nursery schools, 5880 pupils and 136 nursery school teachers across 38 provinces (Oktay 1983). An important milestone was the Law for Educational Organisation that was promulgated in 1926. This law brought new arrangements such as the ban on opening schools without the permission or agreement of the Ministry of National Education (MoNE) and provided that the MoNE is fully responsible for preparing the curricula. The education institutions formerly directed by local governments or religious groups were put under the responsibility of the MoNE. This centralist approach to education was applied to all sectors of education, that is, from pre-primary schools to higher education, and it continues to have an influence in today's Turkey (Ŏguzkan and Oral 2003; Oktay 1983).

The modernisation continued with the alphabet reform in 1928, which introduced the (Western) Latin-based alphabet. After that date, the primary goal of the Republic was to decrease the number of illiterate people. Therefore, investment priority was given to primary education and adult education and no significant investment could be made in pre-school education. Policies for early childhood education only (re) emerged in the 1950s and 1960s, that is, after a relative increase in the literacy rate was reached (Kapci and Güler 1999; Poyraz and Dere 2003). The period with the fastest progress in the political and legal organisation of pre-school education in Turkey was that between 1960 and 1990. Regulations were mainly steered by two central government institutions: these are the National Education Council (Milli Eğitim Şurast) and the Development Plans. The National Education Council is the official advisory committee that provides recommendations to the MoNE. Since their establishment in 1939, the National Education Councils have paid special attention to early childhood education and they have had substantial effect on policies from 1953 until today. For instance, the National Education Councils in 1953 took the decision to open state-funded pre-school education institutions, the Council held in 1962 focused on teacher training for pre-schools, and the Council held in 1993 met to increase pre-school attendance rate and expand the pre-primary schooling system (Akyüz 2008). It was in this period that the Government of Turkey recognised the critical role played by early lifecycle investments in achieving equitable and sustainable development.

Thus, expansion of pre-primary education was regarded by Turkish policy-makers as a means of political development and economic growth. That is the reason why early childhood was also a returning topic within various Development Plans. Equally, organised by the central government, the Development Plans outline the priorities for policies and investments to be made in Turkey, mainly for the sake of economic growth. The Development Plan covering the years 1979-1983 included a decision to 
start a pilot programme for the children of slums and rural areas. Within the Development Plan covering the years 1985-1989, it was decided to increase the pre-school schooling rate to $10 \%$ and to open preparatory schools particularly for the children of 60-72 months in primary schools. In the Development Plans 1995-2005, it was planned to increase the schooling rate to $16 \%$. The Development Plan of 2007-2013 included decisions to train teachers for pre-school education and to diversify pre-school education services (Dağlı and Dağlı 2012; Kapci and Güler 1999).

\section{Current structure and policies}

According to official statistics for the school year 2013-2014 (see MEB 2014), about one million Turkish pupils are enrolled in pre-schools, of which $87 \%$ are in the public and $13 \%$ in the private sector. Within both sectors, two types of early childhood education are distinguished. First, there are the pre-primary classes (Anasiniflarl) which are preparatory classes within primary schools (so similar to, e.g. kindergarten in the USA). In 2014 , there were 21,268 pre-primary classes which account roughly for $66 \%$ of the total pre-school enrolment. Secondly, there are independent pre-schools (bağımsız ana okulu). In 2014, there were 3729 independent pre-schools, which account roughly for $28 \%$ of the total pre-school enrolment. A smaller number of students are enrolled in pre-school institutions created for civil servants and by institutions set up by the Child Protection Agency (MEB 2014).

Pre-primary classes and independent pre-schools function both on a daily basis, five days a week. The daily programme includes 6 times 50 minutes of learning activities focusing on language and literacy skills, social skills, creative and problem-solving skills, appreciation of music and movement, and outdoor play. In some places, education is delivered in shifts, with different children in morning and afternoon classes. The MoNE is responsible for drawing up curricula, designing and building schools, training teachers, and developing educational materials.

More recently, the Government of Turkey made early childhood education a national priority. While the reason behind this change is not clear, it is likely that pressure to meet the targets set by international organisations (EFA commitments, OECD, etc.) may have played a role. In 2010, the MoNE set up a target to reach $50 \%$ participation in pre-primary education for children aged 36-72 months (MEB 2010). In 32 different cities, the MoNE organised pilots to increase the attendance rate. However, these pilots were concentrated in provinces that already had higher attendance rates. This is based on the idea that those provinces are less likely than others to need new infrastructure, thus making it easier to accumulate quick gains in reaching enrolment targets. As a consequence of this policy choice, the already high inequalities in attendance across different provinces further increased. For instance, the pre-school enrolment rates for 3-5 year-olds are as low as $15.66 \%$ in the province of Hakkari in the south-east of Turkey, and as high as $50.41 \%$ in the Black Sea province of Amasya. With the exception of Istanbul, the enrolment rates are much higher in the Western part of the country and lower in the Eastern and the Southern parts of the country (MEB 2014).

It should be noted that most recent reforms of the Government of Turkey are confusing and partly contradictory with respect to pre-schooling. On the one hand, the government had decided to make pre-primary school education compulsory for five-year-olds in 2010. However, this policy has been suspended in 2012. At the same time, the starting age of compulsory schooling at primary school is lowered to 
five and a half years with the so-called ' $4+4+4$ ' educational reforms. According to educators, the latter reform created ambiguities and consequently reduced the attendance rate for pre-schooling, as many parents were confused as to whether pre-primary school is compulsory and at what age it starts. Moreover, many educators report that they are ill informed on the contents of the educational reform with respect to preschooling (Çivik, Ünüvar, and Soylu 2015).

\section{Academic benefits of pre-school: what does the international evidence say?}

A key question in international research is whether attending pre-school has any academic benefits for children. International studies differ in the timespan of their focus: effects at short, middle and long term are distinguished that respectively refer to effects on primary education, secondary education and beyond. Moreover, a distinction should be made between general and equity effects of pre-school. General effects refer to average advantages for the entire group that attend pre-school. Equity effects concern the issue as to whether pre-school attendance shows differential gains for children from advantaged/disadvantaged groups. It should be noted that the present study will examine middle-term academic effects of pre-school participation, and both general effects and equity effects will be investigated.

Most studies on the academic impact of pre-school education have been conducted in the USA. Reviews and meta-analyses have established over the years that early childhood programmes in the USA have substantive positive short-term and moderate longer term effects on the cognitive-academic development of children (Manning, Homel, and Smith 2010). An earlier study by Barnett (1995) reviewed 36 studies on a variety of early childhood programmes to examine the long-term effects of these programmes on children from low-income families. The study focused primarily on cognitive development. The results indicate that early childhood programmes can produce large short-term benefits for children on intelligence quotient and sizable long-term effects on school achievement, grade retention, placement in special education, and social adjustment. A more recent review by the same author (Barnett 2011) reaches the conclusion that early educational intervention can have substantive short- and long-term effects on cognition, social-emotional development, progress through school, antisocial behaviour and even crime. A broad range of approaches, including large public programmes, have demonstrated effectiveness. Long-term effects may be smaller than initial effects, but they are not insubstantial. The meta-analysis by Gorey (2001) integrated results across 35 pre-school (quasi-)experiments. The study found pre-school effects on standardised measures of intelligence and academic achievement which were significant, positive and large. In addition, cognitive effects of relatively intense educational interventions were significant and very large, even after 5-10 years. Nelson, Westhues, and MacLeod (2003) also used meta-analysis to examine the effect sizes of 34 pre-school prevention programmes in the USA. The results indicate that pre-school programmes did have short-, medium- and long-term impacts on several outcome domains (cognitive, social-emotional, parent-family wellness). Cognitive effects were greatest during the pre-school period, but were still evident during elementary and middle school, and high school and beyond. The longer (more than one year) and the more intensive the interventions for children, the greater were the impacts on pre-school cognitive outcomes. A more recent metaanalytic review (Manning, Homel, and Smith 2010) of early developmental prevention programmes, including structured pre-school programmes, delivered to at-risk 
populations, investigated non-health outcomes during adolescence (educational success, cognitive development, social-emotional development, family well-being, etc.). Seventeen studies, based on 11 interventions (all US-based), were included in the analysis. The largest effect was observed for educational success during adolescence. Results were clear, too, for programme intensity and duration, where it seems that, in a nutshell, more is better. The recent and very extensive meta-analysis conducted by Camilli et al. (2010) analysed a total of 123 comparative studies (published between 1960 and 2003) of early childhood education programmes in the USA, looking at the magnitude of cognitive and affective gains. The results are consistent with the accrued research base on the effects of pre-school education. Significant effects were found for children who attend a pre-school prior to entering kindergarten. The largest effects were observed for cognitive outcomes, although a pre-school education was also found to impact children's social skills and school progress. However, all the above-mentioned studies involve almost exclusively targeted pre-school and care programmes, implying that disadvantaged children are the main beneficiaries. Observing cognitive benefits of pre-school attendance for these children is by itself no proof of equity effects. On the basis of the US studies, it remains unclear whether other types of pre-school education, particularly universal pre-school, have similar benefits, and whether there are differential effects of attendance of universal pre-school for advantaged and disadvantaged children. In this connection, Barnett and Belfield (2006) pointed out that pre-kindergarten programmes in the USA raised academic skills on average, but did not appear to have notably different effects for different groups of children, and so did not strongly enhance social mobility.

International studies in other contexts are broadly consistent with the results of research from the USA. The meta-analysis by Nores and Barnett (2010) reviewed the international (non-USA) evidence on the benefits of early childhood interventions. A total of 56 studies reporting effects of 30 interventions in 23 countries in Europe, Asia, Africa, Central and South America were analysed. The study found that children from different contexts and countries receive substantive cognitive, behavioural, health and schooling benefits from early childhood interventions. Also, the benefits were sustained over time. Another study conducted by Burger (2010) reviewed 32 key studies assessing the effects of 23 pre-school programmes in Europe, the USA and elsewhere on cognitive development. Programme start, intensity and duration were considered. The findings indicate that the vast majority of recent early education and care programmes had considerable positive short-term effects, and somewhat smaller longterm effects on cognitive development.

Looking specifically at the international evidence on equity effects, a rather mixed pattern emerges from the review by Burger (2010). A number of studies showed that the main beneficiaries of pre-school interventions are children from low socio-economic status (SES) families. However, other reviewed studies did not consistently report larger gains for these groups. On the other hand, Nores and Barnett (2010) found partial evidence for larger effects of interventions with more disadvantaged children on schooling outcomes, that is, less school failure and dropout.

The international PISA (Programme for International Student Assessment) 2009 assessment provides additional cross-national evidence with respect to both determinants of access and academic effects of pre-school participation of 15-year-old students in 65 countries (OECD 2011) (see Methods section below for some details on the PISA studies). With respect to access to pre-school, the report concludes: 'Disadvantaged students have less access to pre-primary education than advantaged students in almost 
every country, particularly those in which pre-primary education is not widespread' (OECD 2011, 1). Moreover, the results pointed out that even after controlling for SES, students who had attended pre-primary school performed better in reading at age 15 than students who had no pre-school experience. The more recent PISA 2012 study has shown a similar pattern with respect to mathematics achievement. In OECD countries, a score difference of 53 points in mathematics was found, which decreased to 31 points after accounting for SES (OECD 2013). When the relationship between pre-school participation and performance in mathematics was compared between different socio-economic backgrounds, there was no overall significant difference between students from socio-economically disadvantaged and advantaged backgrounds, except in a number of countries where the performance advantage of attending pre-school was greater for advantaged students (e.g. Portugal, Romania, Uruguay). The study does not provide a clear explanation for this difference across countries. The previous PISA 2009 study argues that part of the variation in the strength of the relationship between pre-primary attendance and the socio-economic background of students may be due to the fact that many other factors apart from pre-primary attendance (e.g. education in and out of school that students received between the age of 6 and 15) may influence the performance of 15-year-olds (OECD 2010). Also, other studies do not provide clear answers for this cross-country difference, or have not addressed this particular issue. One may assume a relationship between aggregate pre-school participation rates and reduction of social gaps in school attainment. However, Green and Mostafa (2011) concluded from cross-national analyses of the PISA 2009 data that there was little evidence to support the larger claim that high levels of pre-school education participation mitigated social gaps in performance at age 15. Pre-school participation increased educational performance by similar amounts for all social groups in most countries. The authors further claim that social gaps in performance may only be mitigated by high levels of pre-school provision where children from less advantaged families get more - or better quality - provision. Another explanation for favourable differential effects of pre-school attendance for advantaged children may, therefore, lie in differences in pre-school quality. Prochner (as cited in Boocock 1995), who reviewed early childhood programmes from an international perspective, asserts that in many nations, poor children are being provided with substandard programmes, often in the public system of early education, while children from the middle and upper classes are offered pre-school education in a separate, usually higher quality, private service.

Another issue considered in this paper is the relation of gender to access to pre-primary education. In general, girls and women remain deprived of full and equal opportunities for education, especially in very poor countries and regions (Lockheed 2008; Stromquist 2007). It is assumed that access of girls to pre-school education has, apart from economic gains, several gender-related benefits - such as allowing the mother to do productive work, freeing the elder sister to attend school, helping the professional development of the mother as a pre-school assistant or teacher, and, more generally, the empowerment of the mother, bringing benefits also to the local community (EFA GMR 2003, 183). The global community, through international organisations like UNESCO, UNICEF and the World Bank, has long been interested in promoting gender equality in education at all levels, including pre-primary education. One would reasonably expect that girls are more likely to be out of pre-school, especially in societies characterised by marked son-preference and by discrimination against daughters from the early years of life (EFA GMR 2003). However, a recent 
UNESCO study (2012) found that gender parity is generally strong in the area of pre-primary education, confirming the outcomes of earlier reports drawn up by the EFA GMR team (EFA GMR 2003, 2006). Girls and boys participate in pre-primary education at the same rates in a substantial majority (62\%) of countries. Males are favoured in $18 \%$ of countries and females in $20 \%$. Furthermore, girls account for $49 \%$ of the worldwide increase of $64 \%$ in enrolment in pre-primary schooling and around half of total pre-primary enrolment in 2012 (EFA GMR 2015). In 2005, the Gender Parity Index (GPI) - the ratio between the female and male GER (Gross Enrolment Ratio; see further for definition)) - was close to, or exceeded, 0.90 in all regions; and 105 of the 169 countries with available data were at gender parity, including 23 more countries than in 1999 (EFA GMR 2008). For Turkey in particular, the GPI was 0.94 in 1999 and 0.97 in 2012, which, although improving over the years, is apparently still against girls - yet the disparities (above 0.90 ) are not really significant (EFA GMR 2003, 2015). The small universal gender disparities at pre-primary level can be explained by two opposing forces: wealthy parents do not discriminate between sons' and daughters' pre-school education, and poor children are benefiting through less formal educational approaches that seek to empower women and girls. The study of Stromquist (2007) (see also EFA GMR 2003; UNESCO 2012) asserts that one reason for the high level of parity in the earliest years of schooling may be that, especially in developing countries, it is the wealthier and better educated families who enrol their children in pre-primary schools, and such families are more inclined to value schooling for both boys and girls. Such is certainly the case in situations where pre-school involves costs to the families. Those parents who can afford to send their children to private pre-schools are less likely to be forced to be selective by enrolling only their sons (EFA GMR 2003). The second reason is that developing countries where the total enrolment in pre-school is low often have a large non-formal sector consisting of programmes targeting poorer groups. Girls are likely to enrol in roughly equal numbers to boys in such targeted programmes because reduction of gender inequality and empowerment of women are often among their explicit goals (EFA GMR 2003). Girls' access to early childhood education is considerably better than their access to primary and secondary education. However, girls from the poorer and less educated families are still more at risk to be out of pre-school, especially in developing countries where public low-cost provision of pre-primary education is limited.

\section{Methods}

For the first two research questions, we made use of the World Bank EdStats All Indicator Query of 17 December 2014. The data include information on pre-primary school enrolment rate for most countries of the world. Two types of enrolment rates are included. GER is defined as the total enrolment in pre-primary education, regardless of age, expressed as a percentage of the total population of official pre-primary education age. For Turkey, GER time-series are available from 1971 onwards. Net Enrolment Rate (NER) is defined as the ratio of children of the official pre-primary school age who are enrolled in pre-primary school to the total population of the official pre-primary school age. For Turkey, NER time-series are available from 2004 to 2013. It should be noted that both ratios largely overlap. For the first research question, we will look at the trend of GER in Turkey after 1971. For the second research question, we will compare NER across 120 countries in 2011, which is the most recent year with available information from most countries. 
For the remaining three research questions, the PISA 2012 data will be used. PISA is a study by the OECD that focuses on the academic performance of 15 -year-old students. In Turkey, 4848 students participated in the PISA 2012 study. Students were asked to provide retrospective information on whether they participated in preschool. There were three answering options: (1) did not participate, (2) participated for one year or less (3) participated for two years and more. We summed up options 2 and 3 to construct a variable that measures any experience with pre-school. As the participants of the PISA study are 15-year-old students, the information in PISA 2012 represents roughly the pre-school enrolment between the years 2000 and 2002, that is, when the respondents were 3-5 years old.

For the third research question, the percentage of girls and boys is compared with respect to the three indicators of pre-school participation. A similar comparison is made for social class, which is measured by the occupational status of the parents; the highest score of both parents is taken as an indicator of social class (PISA 2012 variable Highest International Social and Economic Index (HISEI) is used). Four social classes are distinguished: the poor (below 1 Standard Deviation (SD) of the mean HISEI), lower middle class (between minus $1 \mathrm{SD}$ and mean HISEI), higher middle class (between mean HISEI and plus $1 \mathrm{SD}$ ), upper class (above $1 \mathrm{SD}$ of the mean HISEI). Analysis of variance and $F$-test are used to determine statistical differences.

For the fourth and fifth research questions, the impact of pre-school attendance on reading and mathematical achievement is estimated by using regression analysis of PISA 2012 data. The PISA achievement tests are paper-and-pencil tests consisting of multiple-choice items and short essay questions. They measure the amount of knowledge and skills that students have learnt at school. The emphasis of the items is on the application of acquired knowledge in real-life contexts. The performance in each domain is standardised on a scale with a mean of 500 test-score points and a SD of 100 test-score points across the OECD countries (see OECD 2013). Three models are estimated. In the first model, the raw impact of experience with any pre-school on mathematics and reading achievement at age 15 is calculated. In the second model, we control for social class to rule out selection effects (upper class is used as a reference category). The third model is estimated to examine the fifth research question; we calculated interaction terms between pre-school attendance and social class to investigate differential effects.

\section{Results}

\section{Trends in attendance rate}

In Figure 1, GER in pre-school in Turkey is shown for the years 1971-2012. It is clear that the percentage of pupils who were enrolled in pre-school was negligible until 1985: it was less than $1 \%$. Until the beginning of the twenty-first century, the enrolment ratio was still below 7\%. However, starting from 2003, pre-school attendance grew exponentially and in 2012, it reached $30.6 \%$. This reflects the governments' attempts to increase the attendance rate as described above, but also a global trend in the increase of the preschool attendance rate.

\section{International comparison}

In Table 1, 120 countries are ranked according to their NER in 2011. The list indicates that Turkey has a very low level of pre-school attendance. That is, with $29 \%$, it is ranked 90th among 120 countries. It is also clear that Turkey has the lowest enrolment 


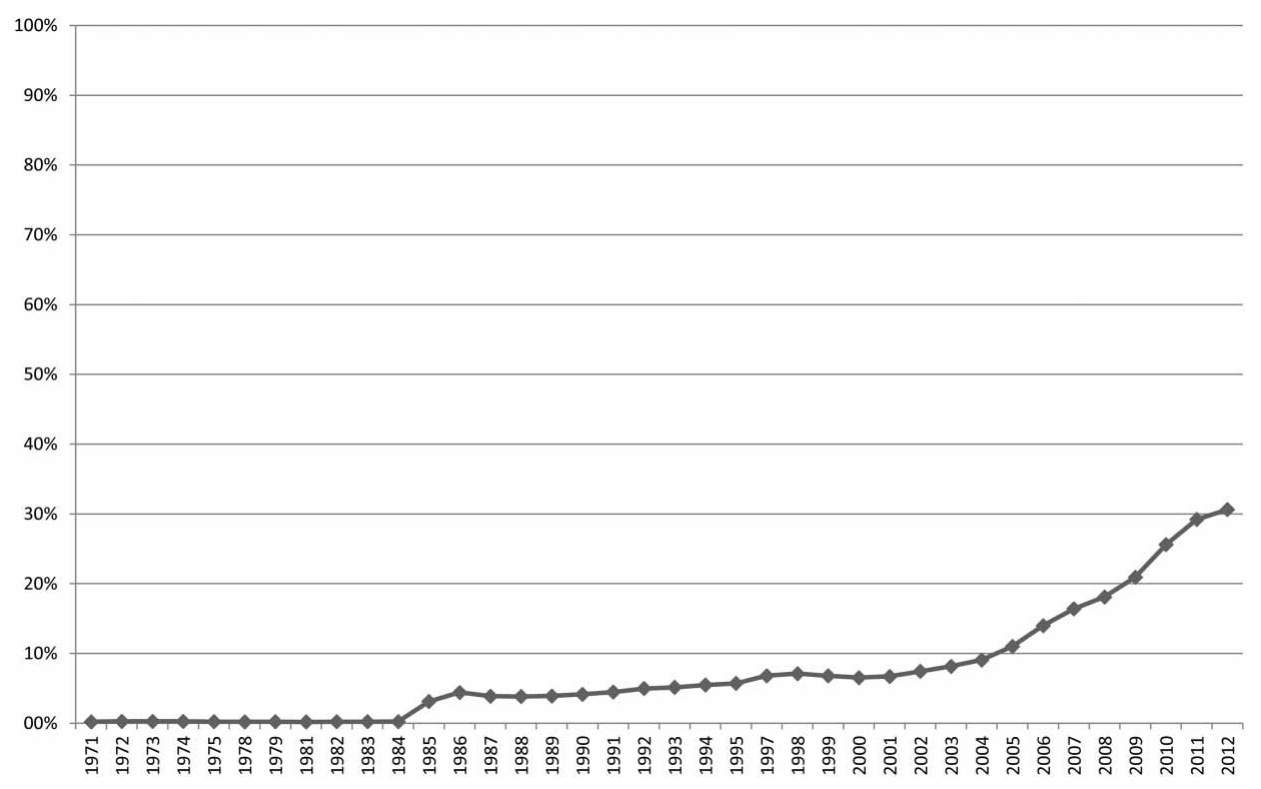

Figure 1. GER in pre-primary school in Turkey 1971-2012 (Source: World Bank, EdStats).

rate among the so-called newly industrialised countries (e.g. Mexico $=81 \%$; Malaysia $=62 \%$; Thailand $=100 \%$ ). There are even many developing countries that have a higher enrolment rate than Turkey such as Morocco (56\%), Honduras (40\%), or Angola (65\%). There is almost no industrialised country with enrolment rates below $65 \%$.

\section{Access to pre-schooling}

Is access to pre-school in Turkey determined by pupils' gender and social class background? According to PISA 2012 data (which reflect the effects of attending preschooling between 2000 and 2002), girls and boys have about the same probability to attend pre-school (see Table 2). Gender is not significantly related to 1 year or less pre-school enrolment $(F=0.273, p=.601)$; neither is gender associated with more than 1 year of pre-school attendance $(F=1.796, p=.180)$. However, the results in Table 3 point out that students' social class background is related to all indicators of pre-school enrolment. For instance, $22 \%$ of pupils from upper social class attend more than 1 year of pre-school, while this is only the case for $3.2 \%$ of pupils from poor families. Pupils from lower middle class $(4.0 \%)$ and higher middle class $(10.1 \%)$ families take an intermediate position. These differences are statistically significant $(F=82.892$, $p<.001)$. Access to 1 year or less pre-school $(F=47.681, p<.001)$ and the chance that pupils attended have any experience in pre-school $(F=82.892, p<.001)$ are both significantly associated with pupils' social class background. Hence, in general, the likelihood to attend pre-school increases with the social class background of pupils.

\section{Impact of pre-school enrolment}

What is the middle-term impact of pre-school enrolment on students' academic performance? Using the PISA data, Table 3 and Table 4 provide the effects of 
Table 1. NER in pre-primary school in 2011 across 120 countries (Source: World Bank, EdStats).

\begin{tabular}{|c|c|c|c|c|c|c|c|c|c|c|c|}
\hline Rank & Country & Rate (\%) & Rank & Country & Rate $(\%)$ & Rank & Country & Rate (\%) & Rank & Country & Rate $(\%)$ \\
\hline 1 & Thailand & 100 & 31 & UK & 80 & 61 & Malaysia & 62 & 91 & Samoa & 25 \\
\hline 2 & France & 100 & 32 & St. Kitts \& Nevis & 78 & 62 & Mongolia & 62 & 92 & Egypt, Arab Rep. & 24 \\
\hline 4 & Mauritius & 99 & 34 & Romania & 77 & 64 & UA Emirates & 59 & 94 & Macedonia, FYR & 24 \\
\hline 5 & Norway & 99 & 35 & Lithuania & 76 & 65 & Panama & 56 & 95 & Azerbaijan & 23 \\
\hline 6 & Israel & 98 & 36 & Switzerland & 76 & 66 & Morocco & 56 & 96 & Lao PDR & 21 \\
\hline 9 & Malta & 97 & 39 & Moldova & 76 & 69 & Guyana & 53 & 99 & Swaziland & 18 \\
\hline 10 & Iceland & 97 & 40 & Argentina & 74 & 70 & Serbia & 53 & 100 & Kyrgyz Republic & 17 \\
\hline 11 & Denmark & 96 & 41 & Peru & 74 & 71 & Qatar & 50 & 101 & Cambodia & 12 \\
\hline 12 & Sweden & 95 & 42 & Algeria & 72 & 72 & Bahrain & 49 & 102 & Rwanda & 11 \\
\hline 13 & Belarus & 94 & 43 & Russian Fed. & 72 & 73 & Sao Tome & 48 & 103 & Congo, Rep. & 11 \\
\hline 14 & Italy & 92 & 44 & Barbados & 72 & 74 & Guatemala & 48 & 104 & Guinea & 11 \\
\hline 19 & Korea, Rep. & 89 & 49 & Venezuela, RB & 71 & 79 & Oman & 43 & 109 & Senegal & 9 \\
\hline 20 & Slovenia & 89 & 50 & Liechtenstein & 70 & 80 & St. Lucia & 43 & 110 & Eritrea & 9 . \\
\hline 21 & Latvia & 88 & 51 & Vietnam & 70 & 81 & Honduras & 40 & 111 & Tajikistan & 7 \\
\hline 22 & Japan & 87 & 52 & Cabo Verde & 70 & 82 & Palestine & 37 & 112 & Central African Rep. & 6 \\
\hline 23 & Suriname & 86 & 53 & Finland & 69 & 83 & Montenegro & 37 & 113 & Niger & 5 \\
\hline 24 & Luxembourg & 86 & 54 & United States & 68 & 84 & Dominican Rep. & 35 & 114 & Burundi & 4 \\
\hline
\end{tabular}


Table 1. (Continued).

\begin{tabular}{llcccccccccc}
\hline Rank & Country & Rate (\%) & Rank & Country & Rate (\%) & Rank & Country & Rate (\%) & Rank & Country & Rate (\%) \\
\hline 25 & Hungary & 84 & 55 & Ireland & 67 & 85 & Solomon Islands & 35 & 115 & Congo, Dem. Rep. & 4 \\
26 & Puerto Rico & 84 & 56 & Australia & 66 & 86 & Gabon & 35 & 116 & Djibouti & 4 \\
27 & Chile & 82 & 57 & Brunei & 65 & 87 & Jordan & 34 & 117 & Mali & \\
28 & Bulgaria & 82 & 58 & Angola & 65 & 88 & Paraguay & 32 & 118 & Burkina Faso & 3 \\
29 & Lebanon & 82 & 59 & Antigua & 64 & 89 & Bermuda & 30 & 119 & Chad & \\
30 & Mexico & 81 & 60 & Croatia & 64 & 90 & Turkey & 29 & 120 & Yemen, Rep. \\
\hline
\end{tabular}

Table 2. Pre-School attendance rates by gender and social class (Source: PISA 2012).

\begin{tabular}{lccc}
\hline & 1 Year or less (\%) & More than 1 year (\%) & Any pre-school (\%) \\
\hline Gender & & & 9.0 \\
Female & 20.8 & 7.9 & 29.8 \\
Male & 21.4 & & \\
Social class & & 3.2 & 17.1 \\
Poor & 13.9 & 4.0 & 19.7 \\
Lower middle class & 15.7 & 10.1 & 38.6 \\
Higher middle class & 28.4 & 22.0 & 54.6 \\
Upper class & 32.6 & & \\
\hline
\end{tabular}


Table 3. Regression analysis of reading achievement: unstandardised effects and standard errors (between parentheses) and $p$-values (Source: PISA 2012).

\begin{tabular}{|c|c|c|c|}
\hline & Model 1 & Model 2 & Model 3 \\
\hline Intercept & $461.69(1.35) * * *$ & $504.23(3.25) * * *$ & $491.26(4.30) * * *$ \\
\hline Any pre-school & $49.5(2.49) * * *$ & $37.56(2.68) * * *$ & $61.30(5.82) * * *$ \\
\hline \multicolumn{4}{|l|}{ Social class } \\
\hline Poor & - & $-55.15(4.53) * * *$ & $-42.50(5.63) * * *$ \\
\hline Lower middle class & - & $-47.23(3.52) * * *$ & $-32.30(4.73) * * *$ \\
\hline Higher middle class & - & $-32.83(3.72) * * *$ & $-18.07(5.19) *$ \\
\hline Upper class (=ref) & - & ref & ref \\
\hline \multicolumn{4}{|c|}{ Pre-school $\times$ social class } \\
\hline Poor & - & - & $-21.81(11.56) * *$ \\
\hline Lower middle class & - & - & $-33.66(7.29) * * *$ \\
\hline Higher middle class & - & - & $-28.39(7.46) * * *$ \\
\hline Upper class (=ref) & - & - & ref \\
\hline
\end{tabular}

pre-school attendance on, respectively, reading achievement and mathematical achievement. Model 1 in both tables indicates that pupils who had any experience with preschool outperformed pupils who did not attend pre-school: a difference of 50 points is found, which corresponds to a difference of $0.50 \mathrm{SD}(p<.001)$. However, after controlling for pupils' social class, the advantage of pre-school enrolment decreases to 37.56 points for reading (see Model 2; Table 3) and to 41.07 points for mathematics

Table 4. Regression analysis of math achievement: unstandardised effects and standard errors (between parentheses) and $p$-values (Source: PISA 2012).

\begin{tabular}{lccc}
\hline & Model 1 & \multicolumn{1}{c}{ Model 2 } & \multicolumn{1}{c}{ Model 3 } \\
\hline Intercept & $433.82(1.48) * * *$ & $478.35(3.59) * * *$ & $460.49(4.75) * * *$ \\
Any pre-school & $53.32(2.73) * * *$ & $41.07(2.29) * * *$ & $73.76(6.42) * * *$ \\
Social class & & & \\
Poor & - & $-58.06(5.01) * * *$ & $-38.92(6.22) * * *$ \\
Lower middle class & - & $-50.08(3.89) * * *$ & $-30.58(5.21)^{* * *}$ \\
Higher middle class & - & $-33.43(4.11) * * *$ & $-11.89(5.73) * *$ \\
Upper class (=ref & - & ref & ref \\
Pre-school $\times$ social class & - & - & $-40.18(11.66) * * *$ \\
Poor & - & - & $-41.05(8.05) * * *$ \\
Lower middle class & - & - & $-42.22(8.42) * * *$ \\
Higher middle class & - & - & ref \\
Upper class $(=$ ref $)$ & - & & \\
$* * * p<.001$. & & & \\
$* * p<.01$. & & & \\
$* p<.05$. & & &
\end{tabular}


(see Model 2; Table 4). Thus, these figures indicate that even after controlling for social class, attending pre-school provides an advantage of about $0.40 \mathrm{SD}$.

\section{Differential effects of pre-school enrolment}

Do all pupils benefit equally from pre-school enrolment? To answer this question, the statistical interaction term between social class and pre-school attendance is calculated. These differential effects of pre-school enrolment on reading and mathematical achievement are, respectively, shown in the third model of Table 3 and Table 4 . The statistically significant interaction terms indicate that pupils from wealthy (upper class) families benefit more from pre-school participation than pupils from lower social classes. For instance, while pre-school gives an advantage of 61.30 points in reading for pupils from the upper class, this is only 27.64 points $(=61.30-33.66)$ for pupils from lower middle class families (see Model 3; Table 3). Similarly, the bonus for attending pre-school is 73.76 points in mathematics for the upper class students, while students from higher middle class, lower middle class and from poor families benefit about 40 points less (see Model 3; Table 4). Thus, while pre-school enrolment has a positive effect for all social classes, students from wealthy families benefit more than students from lower social classes.

\section{Conclusion and discussion}

The first steps to build a system of early childhood education in Turkey were part of the larger modernisation project of Turkey. The imitation of Western secular societies was in fact the steering force behind these early developments. However, for many decades, the main political concern was to decrease illiteracy by increasing enrolment in primary school and by adult learning. Consequently, limited attention was paid to the establishment of early childhood education in Turkey and the de facto enrolment rate remained negligible. This changed in the 1950s and 1960s, as major political and legal steps were taken to increase enrolment in pre-primary education. The most important rationale behind these developments was (and still is) the importance of pre-schooling for economic development: early childhood education is believed to increase the level of human capital of the country, directly through improved educational performance and indirectly through increased availability of a (female) workforce.

The empirical results of this study indicated that the pre-school enrolment rate in Turkey was trivially low until 1984, that it slightly increased between 1985 and 2003 , and that it grew exponentially after 2003 . Still, in 2012 , only $30 \%$ of pupils were enrolled in pre-school. Turkey was only ranked 90th among 120 countries and it had the lowest rate of pre-school attendance among industrialised or newly industrialised countries. According to the World Bank (2013), Turkey's per capita income would suggest a pre-school enrolment rate of over $60 \%$, that is, double the actual figure. Hence, we can conclude that the significant socio-economic progress of the country during the last decade only partly compensated for the low levels of preschool attendance.

Another finding of concern is that access to pre-school is strongly determined by the social class background of students. Indeed, students from wealthy families had more access to pre-school than those from poor families. Students with an upper-class background were five times more likely to attend pre-school for more than a year than students from lower middle-class families and seven times more likely to attend pre-school 
for more than a year than poor children. This might be explained by the fact that preschool provision in Turkey is more prevalent in more developed regions in the West and the North of the country than in the poor provinces in the South and the East (see MEB 2014). A positive finding is that students' gender was not a significant predictor of pre-school attendance: Turkish girls are equally likely to attend preschool as Turkish boys. In general terms, this finding is in line with the international literature.

The results also demonstrated that pre-school attendance was related to future academic performance as it correlated with higher reading and mathematical achievement at the age of 15, even when we take account of social class effects. Given the consistent international evidence for the future academic benefits of pre-school participation across many countries around the world (e.g. Barnett 2011; Burger 2010; Camilli et al. 2010; Nores and Barnett 2010), this comes as no surprise. Turkey is no exception to this almost universal pattern. However, the results demonstrated that students from wealthier families benefited more from pre-school attendance than students from lower middle-class and poor families. The international research evidence (especially the PISA studies) reveals a certain amount of variation across countries in equity effects of pre-school attendance. The results of the present study clearly indicate that Turkey belongs to a (small) group of countries where students from more privileged families profit more from pre-school attendance in their later school career than students from disadvantaged families. The differential effect might be explained by the quality of pre-schools that children from different social class backgrounds attend. There is strong evidence that the immediate effectiveness and sustained school success of pre-school provision is connected to its process quality, particularly features such as curriculum and learning environment, teacher-child interactions in the classroom, and parent involvement (e.g. Burger 2010; Camilli et al. 2010). However, the available data do not allow us to examine this explanation empirically, as we relied on a global approach to estimate the effects of pre-school participation. That is because the data lack information on the quality and context of pre-schools, an important omission, given that the effects of pre-school participation are likely to vary depending on the quality and context of the programme. A second limitation of the data that we have used is that they do not allow us to differentiate pre-primary classes and independent pre-schools. However, the attendance rates and the impact of pre-primary classes versus independent pre-schools might be very different. Both shortcomings should be considered as an opportunity for future studies.

The results of this study have important implications for educational policy in Turkey. First of all, it is rare that an industrialised country as Turkey has such low pre-school participation. Nevertheless, if the pre-school enrolment rate continues to grow as it grew in the last decade, Turkey might soon catch up. While the initial plan to make pre-primary classes compulsory for everyone has been abandoned, the starting age for primary school has recently been lowered to five-and-a-half years. If the pre-school attendance rate could be augmented in future years, the quality of Turkish education might benefit and Turkey might move up in the infamous PISA rankings. However, given the differential effects of pre-schooling documented in this study (wealthy pupils benefited more from pre-school than poor pupils), this could also mean an increase in the level of social inequities in education. Combined with the finding that access to pre-school is already strongly determined by social class, the increase in pre-school provision could be detrimental without social policies that strive for more equity in education. 
Hence, we suggest that education policies should in particular provide access to high-quality pre-school for poor and lower middle-class children. This might increase both the quality and the equity of Turkish education. One promising strategy to increase access for poor children is to expand pre-school provision in less developed provinces at the South-East part of the country, and among the poor areas in larger cities such as Istanbul. Another possible strategy is to raise the overall quality of pre-schools by learning from existing evaluations of the quality of pre-school classrooms in Turkey and by developing ways of promoting good practice with regard to teaching and learning in pre-schools serving poor children.

\section{Disclosure statement}

No potential conflict of interest was reported by the authors.

\section{Notes}

1. For the sake of conceptual clarity, we use the term 'pre-school' in this article consistently in a general sense: it refers to all types of pre-primary education services for children between the age of 2 and the age they enter school.

\section{Notes on contributors}

Orhan Agirdag ( $\mathrm{PhD}$, Sociology) is a tenure track professor at the University of Leuven and assistant professor at University of Amsterdam. Formerly, he was a Fulbright Fellow at the UCLA. His main research interests include inequality in education, educational policy, multilingualism and religiosity. As a multilingual researcher, he writes in English, Dutch, and Turkish. He is regularly invited to give public talks and his opinions are regularly featured in the Belgian media.

Zeliha Yazici (PhD, Education) is an associate professor of education at the Akdeniz University. Her expertise and research interests focus on early childhood education and bilingual language acquisition.

Sven Sierens (MA, Anthropology) is a senior researcher at Ghent University. His expertise and research interests mainly focus on linguistic diversity and multilingual policies in schools and classrooms, diversity and social inequality in education, intercultural education, and educational anthropology.

\section{ORCID}

Orhan Agirdag (i) http://orcid.org/0000-0002-5508-1501

\section{References}

Agirdag, O., P. Van Avermaet, and M. Van Houtte. 2013. "School Segregation and Math Achievement: A Mixed-Method Study on the Role of Self-Fulfilling Prophecies." Teachers College Record 115 (3): 1-50.

Akyüz, Y. 1996. "Anaokullarının Türkiyede Kuruluş ve Gelişim Tarihçesi [The History of the Kindergarten's Establishment and Development in Turkey]." Milli Eğitim 131: 11-18.

Akyüz, Y. 2008. Türk Eğitim Tarihi [History of Turkish Education]. Ankara: Pegem Akademi Yayınlar1.

Barnett, W. S. 1995. "Long-Term Effects of Early Childhood Programs on Cognitive and School Outcomes." The Future of Children 5 (3): 25-50. 
Barnett, W. S. 2011. "Effectiveness of Early Educational Intervention.” Science 333 (6045): 975-978.

Barnett, W. S., and C. R. Belfield. 2006. "Early Childhood Development and Social Mobility." The Future of Children 16 (2): 73-98.

Boocock, S. S. 1995. "Early Childhood Programs in Other Nations: Goals and Outcomes." The Future of Children 5 (3): 94-114.

Burger, K. 2010. "How Does Early Childhood Care and Education Affect Cognitive Development? An International Review of the Effects of Early Interventions for Children from Different Social Backgrounds." Early Childhood Research Quarterly 25 (2): 140-165.

Camilli, G., S. Vargas, S. Ryan, and W. S. Barnett. 2010. "Meta-Analysis of the Effects of Early Education Interventions on Cognitive and Social Development." The Teachers College Record 112 (3): 579-620.

Çivik, S. P., P. Ünüvar, and B. Soylu. 2015. "Pre-School Education Teacher's Opinion About the Implementation of 2013 Pre-School Education Program." Procedia-Social and Behavioral Sciences 174: 693-698.

Dağlı, Ü. Y., and A. Dağl1. 2012. "Early Childhood Education in Turkish Laws and Strategic Plans from the 1950s to Today." Journal of Theoretical Educational Science 5 (4): 454-467.

Duru, K. N. 1915. Çocuk Bahçesi Rehberi. [Kindergarten Guide]. İstanbul: Matbaa-i Amire.

EFA GMR. 2003. Gender and Education for All: The Leap to Equality. Education For All Global Monitoring Report 2003. Paris: UNESCO.

EFA GMR. 2006. Strong Foundations: Early Childhood Care and Education. Report 2007. Paris: UNESCO.

EFA GMR. 2015. Education for All 2000-2015: Achievements and Challenges. Education For All Global Monitoring Report 2015. Paris: UNESCO.

Entwisle, D. R. 1995. "The Role of Schools in Sustaining Early Childhood Program Benefits." The Future of Children 5 (3): 133-144.

Ergin, O. 1977. Türk Maarif Tarihi [Turkish Education History]. Istanbul: Eser Matbaasi.

European Commission. 2014. Key Data on Early Childhood Education and Care in Europe. 2014 Edition. Eurydice and Eurostat Report. Luxembourg: Publications Office of the European Union.

Gökçe, F., and N. Oguz. 2010. "Minority and Foreign Schools on the Ottoman Education System." e-International Journal of Educational Research 1 (1): 42-57.

Gorey, K. M. 2001. "Early Childhood Education: A Meta-Analytic Affirmation of the Short- and Long-Term Benefits of Educational Opportunity." School Psychology Quarterly 16 (1): 9-30.

Green, A., and T. Mostafa. 2011. Preschool Education and Care-A Win-Win Policy? LLAKES Research Paper 32. Centre for Learning and Life Chances in Knowledge Economies and Societies. London. www.llakes.org.

Hattie, J. 2013. Visible Learning: A Synthesis of Over 800 Meta-Analyses Relating to Achievement. London: Routledge.

Heckman, J. J. 2006. "Skill Formation and the Economics of Investing in Disadvantaged Children." Science 312 (5782): 1900-1902.

Kapci, E. G., and D. Güler. 1999. "Pre-School Education in Turkey: Policies and Practices in Their Historical Context." Early Child Development and Care 156 (1): 53-62.

Karoly, L. A., M. R. Kilburn, and J. S. Cannon. 2006. Early Childhood Interventions: Proven Results, Future Promise. Santa Monica, CA: Rand Corporation.

Lamy, C. E. 2013. "How Preschool fights Poverty." Educational Leadership 70 (8): 32-36.

Leseman, P. P. M. 2002. Early Childhood Education and Care for Children from Low-Income or Minority Backgrounds. Paris: OECD.

Lockheed, M. L. 2008. "The Double Disadvantage of Gender and Social Exclusion in Education." In Girls' Education in the 21st Century: Gender Equality, Empowerment, and Economic Growth, edited by M. Tembon and L. Fort, 118-126. Washington, DC: World Bank.

Manning, M., R. Homel, and C. Smith. 2010. "A Meta-Analysis of the Effects of Early Developmental Prevention Programs in at-Risk Populations on Non-Health Outcomes in Adolescence." Children and Youth Services Review 32 (4): 506-519.

MEB (Milli Ĕ̆itim Bakanlı̆̆1). 2010. Cumhuriyet döneminde Türk Milli Ĕ̆itim sistemindeki gelişmeler (1920-2010). [Developments in the Turkish National Education System During the Republican era (1920-2010)]. Ankara: Strateji Geliştirme Başkanlığı. 
MEB (Milli Eğitim Bakanlığı). 2014. Türkiye Ĕ̆itim Istatistikleri 2013-2014 [National Education Statistics Formal Education 2013-2014]. Ankara: Milli Eğitim Bakanlı̆̆ı.

Nelson, G., A. Westhues, and J. MacLeod. 2003. "A Meta-Analysis of Longitudinal Research on Preschool Prevention Programs for Children." Prevention \& Treatment 6 (1): 1-35.

Nores, M., and W. S. Barnett. 2010. "Benefits of Early Childhood Interventions Across the World: (Under)Investing in the Very Young." Economics of Education Review 29 (2): 271-282.

OECD. 2001. Starting Strong: Early Childhood Education and Care. Paris: OECD.

OECD. 2006. Starting Strong II: Early Childhood Education and Care. Paris: OECD.

OECD. 2010. PISA 2009 Results: Overcoming Social Background - Equity in Learning Opportunities and Outcomes. Volume II. Paris: OECD.

OECD. 2011. Does Participation in Pre-Primary Education Translate into Better Learning Outcomes at School? Paris: OECD.

OECD. 2013. PISA 2012 Results: Excellence Through Equity. Giving Every Student the Chance to Succeed. Volume II. Paris: OECD.

OECD. 2015. Starting Strong IV: Monitoring Quality in Early Childhood Education and Care. Paris: OECD.

Oğuzkan, Ş., and G. Oral. 2003. Okul Öncesi Ĕ̆itimi [Pre-School Education]. İstanbul: Milli Eğitim Basımevi.

Oktay, A. 1983. “Türkiye'de Okul Öncesi Eğitimin Dünü ve Bugünü [Pre-School Education in Turkey: Past and Present]." Eğitim ve Bilim Dergisi 7 (42): 3-7.

Poyraz, H., and H. Dere. 2003. Okulöncesi Eğitiminin Ilke ve Yöntemleri [Principles and Methods of Early Childhood Education]. Ankara: Anı Yayınc1lı.

Stromquist, N. P. 2007. "Gender Equity Education Globally." In Handbook for Achieving Gender Equity Through Education, edited by S. S. Klein, B. Richardson, D. A. Grayson, L. H. Fox, C. Kramarae, D. S. Pollard, and C. A. Dwyer, 2nd ed., 33-42. Mahwah, NJ: Lawrence Erlbaum.

UNESCO. 2012. World Atlas of Gender Equality in Education. Paris: UNESCO.

World Bank. 2013. Expanding and Improving Early Childhood Education in Turkey. Report No: 77723-TR. Washington, DC: World Bank. 